\title{
Growth and Characterization Studies of SrCaMHP Single Crystal in Silica Gel Medium and Laser Induced Nucleation Reduction Strategy
}

\author{
G. Kanchana, P. Sundaramoorthi*, and G.P. Jeyanthi \\ Department of Bio-chemistry, Avinashilingam Deemed University, Coimbatore, TamilNadu, \\ India. \\ *Department of Physics, A.A Govt. Arts College, Namakkal, India-637001. \\ (Ph.No.-04286-266313 (off.) Fax-04286-266323 , MailID-moorthi.sundara@gmail,com)
}

\begin{abstract}
SrCaMHP (Strontium Calcium Magnesium Hydrogen Phosphate) crystals were grown in silica gel medium using different gel densities, various concentrations of phosphoric acid and supernatant solutions. The gel $\mathrm{pH}$ plays an important role in the formation of different $\mathrm{HPO}_{4}$ species in the phosphoric system. The growth of SrCaMHP crystals depends upon the $\mathrm{pH}$ of the inner reactant ionic concentration. The characterizations of grown crystals were studied by FTIR, TGA/DTA, SEM, XRD and etching. The results are reported and discussed in detailed manner.
\end{abstract}

Key words: SrCaMHP, SEM, laser light, calculi, surface morphology, growth parameters, trace elements, isotopes.

\section{INTRODUCTION}

SHP (Strontium hydrogen phosphate) and BHP (Barium hydrogen phosphate) were grown in silica gel medium at room temperature and reported $[1,2]$. The next approach is to grow mixed crystal in silica gel medium at different environments, which contains two major elements (Calcium, Phosphate), one minor or trace element (Strontium) and one inhibitor (Magnesium). SrCaMHP is a mixed crystal, which typically represent the biological crystals formed in the human urinary tracts called renal stones. Strontium ( $\mathrm{Sr}$ ) is a silvery-white alkaline earth metal that exists in several stables (e.g. Sr-89, Sr-88) and several radioactive (e.g. Sr-89, Sr-90) isotopes. Strontium is in the fifteenth most abundant element in nature and it is the most abundant trace element in seawater. Thus it can become incorporated in to all plants and animal tissues. The daily intake of strontium 
varies from about 2.8 to 4.0 milligram/day. Of this a negligible quantity is supplied by air, approximately 89 percent by food and the remaining 10 to 31 percent by water. Authors have done a series of experiments with silica gel crystal growth medium at different $\mathrm{pH}$ values ranging from 5.5 to 9 and have proved that one can obtain the periodic precipitations, Liesegang rings [3-5] of biological crystals named as HAP, Brushite, struvite, BMHP and SrMHP etc.

Strontium is present naturally in many foods for example spices, seafood, cereals, grains, leafs and vegetables. There are some evidences that strontium is essential for growth of animals, especially for the calcification of bone and teeth. Metabolism of strontium closely resembles that of calcium, especially with regard to bone. The absorption of strontium varies normally from 10 to 35 percent in injected dose. A $75 \mathrm{~kg}$ standard man contains nearly $330 \mathrm{mg}$ of strontium. The skeleton contains more than 98 percent of the strontium. The rest is distributed among soft tissues; the largest concentration resides in the aorta, larynx, trachea and lower gastrointestinal tract. When administrated orally, it is primarily excreted in the faces. Strontium is a low excreted the sweat and in the milk of lactating females. If the mineral level of the body fluid increases, automatic mineral deposition starts.

\section{MATERIALS AND METHODS}

The dissociation of phosphoric acid system can be represented by three-dissociation equilibrium and the presence of various ions at various $\mathrm{pH}$ values are reported [6]. On the account of these results, the gel $\mathrm{pH}$ in the range from 6 to 10 has been used (Milwaukee QS$\mathrm{MN}$ pH-600, packet digital $\mathrm{pH}-$ meter are used for measurements) in which the $\mathrm{HPO}_{4}{ }^{2-}$ ions dominate or alone exist. This decreases the possibility of SrCaMP crystals occurring during the SrCaMHP growth. The crystallization apparatus employed were glass test tube of $25 \mathrm{~mm}$ diameter and $150 \mathrm{~mm}$ length for single diffusion method (SDP) and. thick walled $30 \mathrm{~mm}$ diameter and $180 \mathrm{~mm}$ long glass $U$ tubes for double diffusion (DDP) method. The chemicals used were Excelar-Qualigens AR grade $\mathrm{SrCl}_{2}, \mathrm{CaCl}_{2}$ and $\mathrm{Mg}\left(\mathrm{NO}_{3}\right)_{2} .2 \mathrm{H}_{2} \mathrm{O}(\mathrm{MW}-258.41)$ and E-Q AR grade phosphoric acid (Sp.gr.1.75). The SMS gel or water glass was prepared as per the literature [7]. One of the reactant phosphoric acid was mixed with silica gel at desired gel density and elevated temperatures. After the gel set, the supernatant mixture (Strontium chloride + Calcium chloride + Magnesium nitrate) at a required mole solution was slowly added along the walls of the growth columns (test tubes, U-tubes) over the set gels and tightly closed to prevent evaporation. The growth parameters of SrCaMHP crystals in SDP, DDP are presented in Table1 and Table 2 respectively. The optimum growth parameters are indicated in bold letters. The growth columns, harvested crystals and different environments growth are shown in Fig. 1-7 then the growth systems were allowed to react within the gel medium and the following chemical reaction takes place.

$\left(\mathrm{SrCl}_{2}+\mathrm{CaCl}_{2}+\mathrm{Mg}\left(\mathrm{NO}_{3}\right)_{2} .2 \mathrm{H}_{2} \mathrm{O}\right)+\mathrm{HPO}_{4}+\mathrm{Set}$ gel $\rightarrow \mathrm{SrCaMgHPO}_{4}+\mathrm{By}$ products --- (1) 
Table-1 Growth parameters of SrCaMHP crystals in SDP growth process.

\begin{tabular}{|c|c|c|c|c|c|c|c|}
\hline $\begin{array}{c}\text { Gel } \\
\text { density } \\
\text { gm/cc }\end{array}$ & $\begin{array}{c}\text { Phosphoric } \\
\text { acid } \\
\text { concentration } \\
\text { (Inner reactant } \\
\text { mixed with } \\
\text { gel) N }\end{array}$ & $\begin{array}{c}\mathrm{Gel}+ \\
\mathrm{HPO}_{4} \\
\mathrm{pH} \\
\text { value }\end{array}$ & $\begin{array}{c}\text { Gel setting } \\
\text { time } \\
\text { hrs }\end{array}$ & $\begin{array}{c}\text { Supernatant } \\
\text { Concentration } \\
\left(\mathrm{CaCl}_{2}+\mathrm{SrCl}_{2}\right)^{+} \\
\mathrm{Mg}_{(}\left(\mathrm{NO}_{3}\right)_{2} . \\
\left.2 \mathrm{H}_{2} \mathrm{O}\right)(\mathrm{M})\end{array}$ & $\begin{array}{c}\text { Nucleation } \\
\text { observed in } \\
\text { hrs }\end{array}$ & $\begin{array}{l}\text { Growth } \\
\text { period } \\
\text { in days }\end{array}$ & $\begin{array}{l}\text { Growth } \\
\text { appearances } \\
\text { Inside the } \\
\text { growth } \\
\text { medium }\end{array}$ \\
\hline 1.03 & $\begin{array}{l}1 \\
1 \\
1 \\
1\end{array}$ & $\begin{array}{l}6.4 \\
6.8 \\
6.9 \\
7.3\end{array}$ & $\begin{array}{c}26 \\
16 \\
1 . \\
\mathbf{1 8}\end{array}$ & $\begin{array}{l}1: 1: 1 \\
- \text { do- } \\
\text {-do- } \\
\text {-do- }\end{array}$ & $\begin{array}{l}16 \\
17 \\
32 \\
89\end{array}$ & 196 & GTC,PC \\
\hline 1.03 & $\begin{array}{l}1.5 \\
1.5 \\
1.5 \\
1.5\end{array}$ & $\begin{array}{l}6.6 \\
6.9 \\
7.1 \\
8.0\end{array}$ & $\begin{array}{c}28 \\
1 \\
3 \\
46\end{array}$ & $\begin{array}{l}\text {-do- } \\
\text {-do- } \\
\text {-do- } \\
\text {-do- }\end{array}$ & $\begin{array}{l}26 \\
\mathbf{1 6} \\
46 \\
66\end{array}$ & 190 & GTC \\
\hline 1.04 & $\begin{array}{l}1 \\
1 \\
1 \\
1\end{array}$ & $\begin{array}{l}6.3 \\
6.8 \\
6.9 \\
7.4\end{array}$ & $\begin{array}{c}34 \\
6 \\
1 \\
68\end{array}$ & $\begin{array}{l}\text {-do- } \\
\text {-do- } \\
\text {-do- } \\
\text {-do- }\end{array}$ & $\begin{array}{l}12 \\
22 \\
28 \\
68\end{array}$ & 140 & GTC,PC \\
\hline 1.04 & $\begin{array}{l}2 \\
2 \\
2 \\
2\end{array}$ & $\begin{array}{l}6.6 \\
6.9 \\
7.1 \\
7.5\end{array}$ & $\begin{array}{c}24 \\
\mathbf{1} \\
12 \\
48\end{array}$ & $\begin{array}{l}\text {-do- } \\
- \text { do- } \\
- \text { do- } \\
- \text { do- }\end{array}$ & $\begin{array}{l}13 \\
\mathbf{1 0} \\
24 \\
72\end{array}$ & 175 & GTC \\
\hline
\end{tabular}

GTC-good transparent single crystals are observed.

PC-Poly crystals are observed.

Table-2 Growth parameters of SrCaMHP crystals in DDP growth process.

\begin{tabular}{|c|c|c|c|c|c|c|c|}
\hline $\begin{array}{c}\text { Gel } \\
\text { density } \\
\text { gm /cc }\end{array}$ & $\begin{array}{l}\text { Phosphoric } \\
\text { acid } \\
\text { concentration } \\
\text { (Inner reactant } \\
\text { mixed with } \\
\text { gel) N }\end{array}$ & $\begin{array}{c}\mathrm{Gel}+ \\
\mathrm{HPO}_{4} \\
\mathrm{pH} \\
\text { value }\end{array}$ & $\begin{array}{l}\text { Gel setting } \\
\text { time }\end{array}$ & $\begin{array}{c}\text { Supernatant } \\
\text { Concentration } \\
\mathrm{CaCl}_{2}+\mathrm{SrCl}_{2}+ \\
\mathrm{Mg}_{2}\left(\mathrm{NO}_{3}\right)_{2} \text {. } \\
\left.2 \mathrm{H}_{2} \mathrm{O}\right)(\mathrm{M})\end{array}$ & $\begin{array}{c}\text { Nucleation } \\
\text { observed in } \\
\text { hrs }\end{array}$ & $\begin{array}{l}\text { Growth } \\
\text { period } \\
\text { in days }\end{array}$ & $\begin{array}{c}\text { Growth } \\
\text { appearances }\end{array}$ \\
\hline 1.03 & $\begin{array}{l}1 \\
1 \\
1 \\
1\end{array}$ & $\begin{array}{l}6.0 \\
6.5 \\
6.9 \\
7.1\end{array}$ & $\begin{array}{c}48 \\
\mathbf{1 6} \\
1 \\
26\end{array}$ & $\begin{array}{l}\text { 2:2:2 } \\
\text {-do- } \\
\text {-do- } \\
\text {-do- }\end{array}$ & $\begin{array}{l}45 \\
\mathbf{2 6} \\
22 \\
90\end{array}$ & 140 & GTC \\
\hline 1.03 & $\begin{array}{l}2 \\
2 \\
2 \\
2\end{array}$ & $\begin{array}{l}6.4 \\
6.9 \\
7.2 \\
8.1\end{array}$ & $\begin{array}{c}36 \\
4 \\
1 \\
98\end{array}$ & $\begin{array}{l}\text {-do- } \\
\text {-do- } \\
\text {-do- } \\
\text {-do- }\end{array}$ & $\begin{array}{l}20 \\
22 \\
86 \\
98\end{array}$ & 170 & GTC,PC \\
\hline 1.04 & $\begin{array}{l}1 \\
1 \\
1 \\
1\end{array}$ & $\begin{array}{l}6.2 \\
6.8 \\
7.2 \\
7.6\end{array}$ & $\begin{array}{c}46 \\
5 \\
3 \\
28\end{array}$ & $\begin{array}{l}\text {-do- } \\
\text {-do- } \\
\text {-do- } \\
\text {-do- }\end{array}$ & $\begin{array}{l}40 \\
22 \\
64 \\
88\end{array}$ & 110 & GTC \\
\hline 1.04 & $\begin{array}{l}2 \\
2 \\
2 \\
2\end{array}$ & $\begin{array}{l}6.2 \\
6.9 \\
7.5 \\
7.9\end{array}$ & $\begin{array}{c}88 \\
\mathbf{1} \\
10 \\
58\end{array}$ & $\begin{array}{l}\text {-do- } \\
\text {-do- } \\
\text {-do- } \\
\text {-do- }\end{array}$ & $\begin{array}{l}20 \\
\mathbf{1 0} \\
32 \\
82\end{array}$ & 170 & GTC,PC \\
\hline
\end{tabular}

GTC-good transparent single crystals are observed.

PC-Poly crystals are observed. 


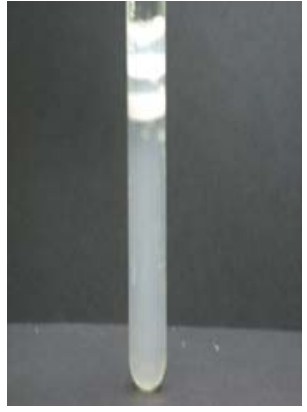

Fig-1

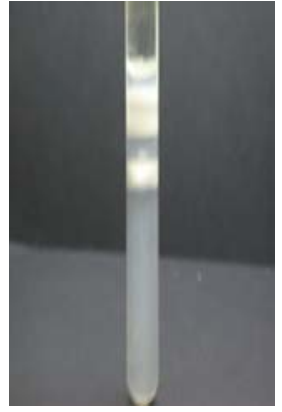

Fig-2

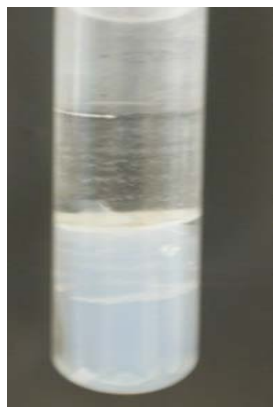

Fig-3

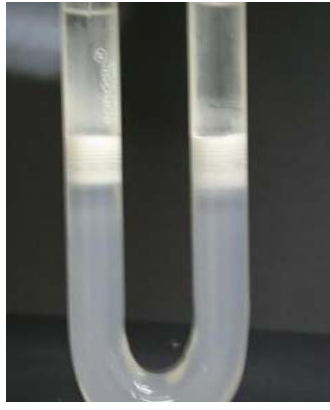

Fig-4

Fig-1 Growth of SrCaMHP crystals in SDP within laboratory environment Fig-2 Growth of SrCaMHP crystals in SDP within laboratory environment Fig-3 Growth of SrCaMHP crystals SDP with the sun light exposed medium Fig-4 Growth of SrCaMHP crystals in DDP within the laboratory medium.

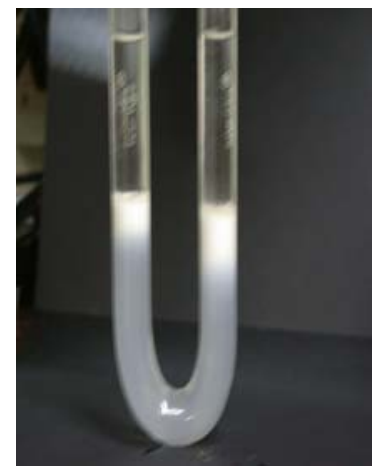

Fig-5

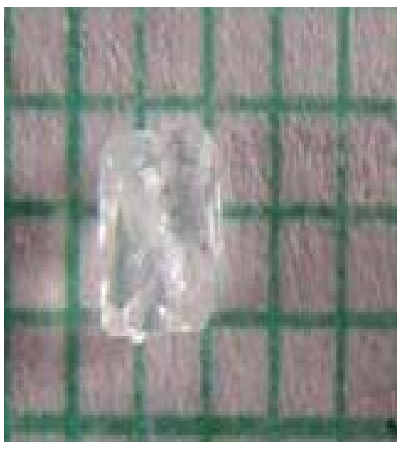

Fig-6

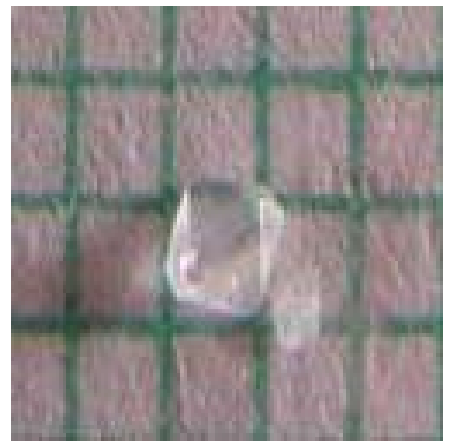

Fig-7

Fig-5 Growth of SrCaMHP crystal with laser exposed medium in DDP

Fig-6 Harvested SrCaMHP crystal in SDP

Fig-7 Harvested SrCaMHP crystal in DDP

\section{CRYSTAL ANALYSIS (Characterization studies)}

\subsection{FTIR spectral analysis of SrCaMHP crystal}

FTIR Spectrometer having $\mathrm{KBr}$ pellets sample holder and $\mathrm{KBr}$ detector was used for the analysis. The $\mathrm{KBr}$ pellet samples were used and the absorption frequencies range from 600 to $4000 \mathrm{~cm}^{-1}$. Fig 8 shows the FTIR spectrum of SrCaMHP crystals. The results match with the reported values [8]. The absorption bonds, absorption frequencies of phosphate group, hydroxyl group in plane and out of plane are analyzed and percentages of transmittance were compared with the reported values. The values are tabulated in Table 3. The functional group frequencies values confirm the SrCaMHP crystal constituents. 


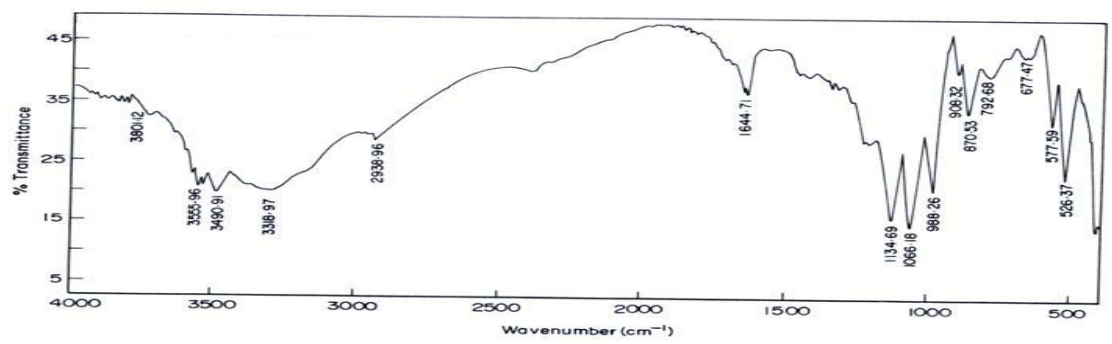

Fig-8, FTIR spectrum of SrCaMHP crystal.

Table-3, FTIR Spectral analysis of SrCaMHP crystal

\begin{tabular}{|l|l|l|l|l|}
\hline SNO & Composition/Bond & $\begin{array}{l}\text { Absorption } \\
\text { frequency } \\
\text { Reported value } \\
\text { cm-1 }\end{array}$ & $\begin{array}{l}\text { Absorption } \\
\text { frequency } \\
\text { observed values } \\
\text { cm-1 }\end{array}$ & $\begin{array}{l}\text { \% } \\
\text { Transmittance }\end{array}$ \\
\hline $\mathbf{1 .}$ & $\begin{array}{l}\text { Sr, } \mathrm{Ca} \text { and Mg \&hydrogen } \\
\text { O -H Symmetric, asymmetric. } \\
\text { (in plane) }\end{array}$ & 3477 to 3207 & 2801 & 3555 \\
& & 3490 & 33 \\
\hline $\mathbf{2 .}$ & O-H out of plane & 745 & 3318 & 18 \\
& & & 792 & 21 \\
\hline $\mathbf{3 .}$ & PO group & 1000 to 1100 & 1134 & 43 \\
& & & 1055 & 15 \\
\hline $\mathbf{4 .}$ & Ca, Sr and Mg / Appetite & $600-1010$ (high & 526 & 15 \\
& group & Frequency) & 577 & 35 \\
\hline
\end{tabular}

\subsection{Thermo gravimetric (TGA and DTA) analysis of SrCaMHP crystal.}

The TGA and DTA of SrCaMHP crystals were carried out by STA 11500-PLTS instruments. The SrCaMHP crystal of $2.439 \mathrm{mg}$ sample was taken to the TGA process. The TGA was started from room temperature to $1000^{\circ} \mathrm{C}$ by heating at a constant rate. Fig. 8 shows the TGA\&DTA graph of SrCaMHP crystals. The $\%$ of weights present in the SrCaMHP sample at a particular temperature was tabulated in Table 4 [10]. 


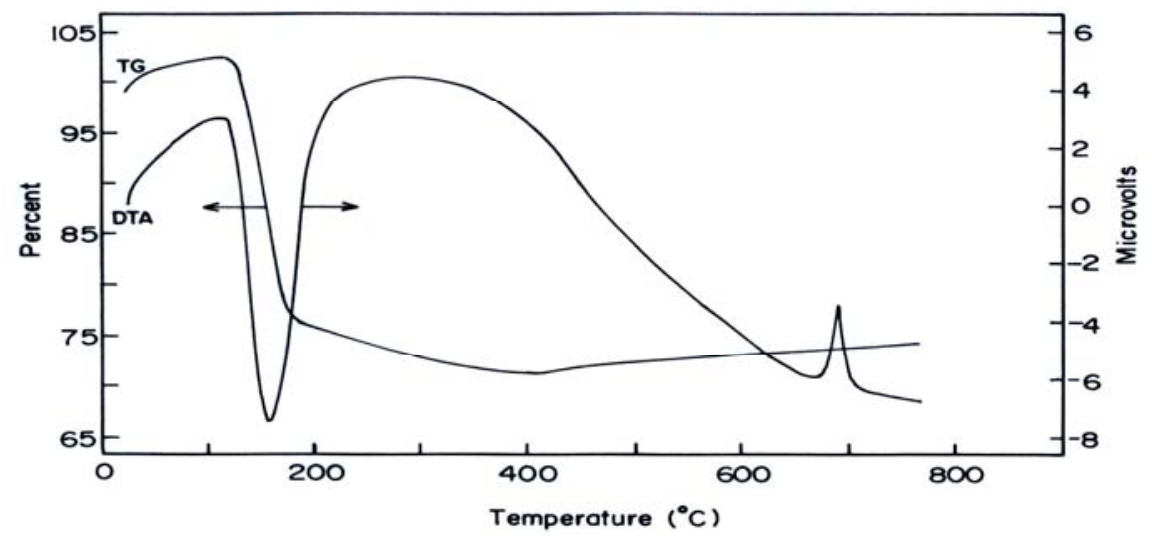

Fig.9. Thermo gravimetric (TGA and DTA) analysis of SrCaMHP crystals.

Table-4. Thermal Analysis of SrCaMHP crystals.

\begin{tabular}{|l|l|l|l|}
\hline Points & \multicolumn{2}{|l|}{ TGA } & DTA in ${ }^{0} \mathrm{C}$ \\
\cline { 2 - 3 } & Temperature $\left({ }^{\circ}\right.$ & $\%$ of SrCaMHP crystal & \\
& C) & present & \\
\hline 1 & 35 & 100 & 114.81 \\
2 & 114 & 102 & 160.60 \\
3 & 179 & 77 & 231.45 \\
4 & 410 & 72 & 672.51 \\
5 & 850 & 72 & 691.53 \\
\hline
\end{tabular}

The TGA of SrCaMHP crystals were anhydrous up to $114{ }^{0} \mathrm{C}$. Here after the remaining sample is stable up to the end of the analysis.

The expected chemical reactions are:

$\mathrm{SrCaMgHPO}_{4} \cdot \mathrm{XH}_{2} \mathrm{O} \underset{\boldsymbol{\Delta}}{\longrightarrow} \mathrm{SrCaMgPO}_{4}+\mathrm{X} \mathrm{H}_{2} \mathrm{O}$-Heating up to $114{ }^{0} \mathrm{C}$---(2)

${ }_{2}^{2 \mathrm{SrCaMgPO}_{4}} \stackrel{\boldsymbol{\Delta}}{\longrightarrow} 2 \mathrm{Sr} \mathrm{Ca} \mathrm{Mg}+2 \mathrm{PO}_{4}$-Heating up to $900{ }^{0} \mathrm{C}$----(3)

$\mathrm{Sr}, \mathrm{Ca}$ and $\mathrm{Mg}$, are stable compounds with respect to the melting points. Twenty-two 
percentages of SrCaMHP crystals were decomposed and $72 \%$ of the sample is stable.

\subsection{Etching study of SrCaMHP crystal}

A well-grown SrCaMHP crystal was immersed in $\mathrm{HCl}$ solution at a desired concentration. The dissolution of SrCaMHP crystal depends upon the etchant concentration, temperature, crystal morphology, etching time etc. [13-16]. The etch pits are shown in Fig. 10. The etch pits observed include helical pits, spiral pits, cone pit, leaf pit and step pits.

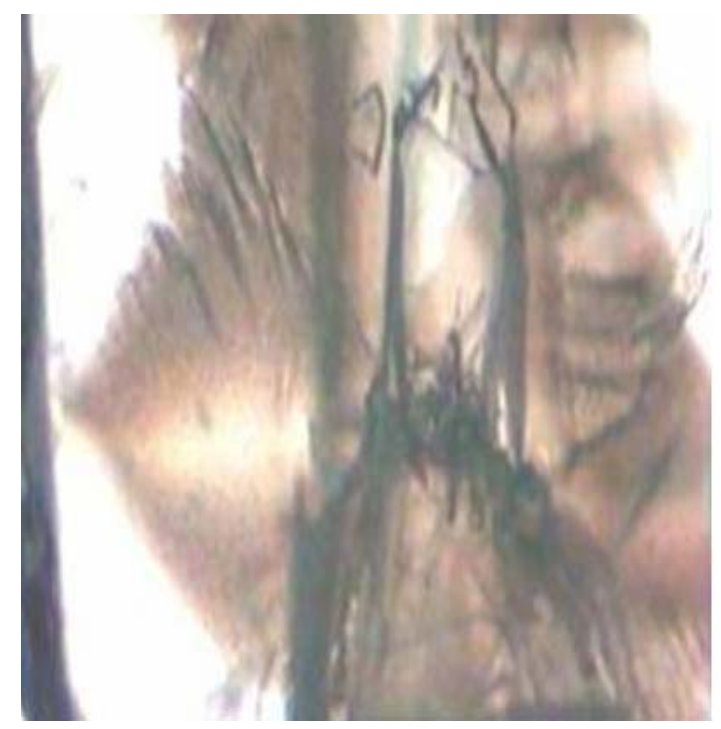

Fig-10. Chemical etching of SrCaMHP crystal at room temperature $\left(30^{0}\right.$ Celsius $) .1 \mathrm{~N} \mathrm{HCl}$ etchant, 6 minutes etching time.

\subsection{Scanning Electron Microscopy Study of SrCaMHP Crystals}

A well-grown SrCaMHP single crystal was selected for the investigation of surface morphology by using SEM. The SEM photograph was made in the version S-300-I instrument. The sample named VCA-600 was kept in lobe middle; the data size was $640 \times 480$. The minor and major magnifications of SEM were about 250 times. SEM acceleration voltage was 25000 volts and the sample was kept in a high vacuum. 18200-micrometer working distance and monochromatic color mode were employed. $200 \mu \mathrm{m}$ focusing of SrCaMHP crystal SEM is shown in Fig. 11. In the surface analysis of SEM-SrCaMHP crystal, few smooth surfaces, many fine grain boundaries and some valley regions are observed [17-20]. 


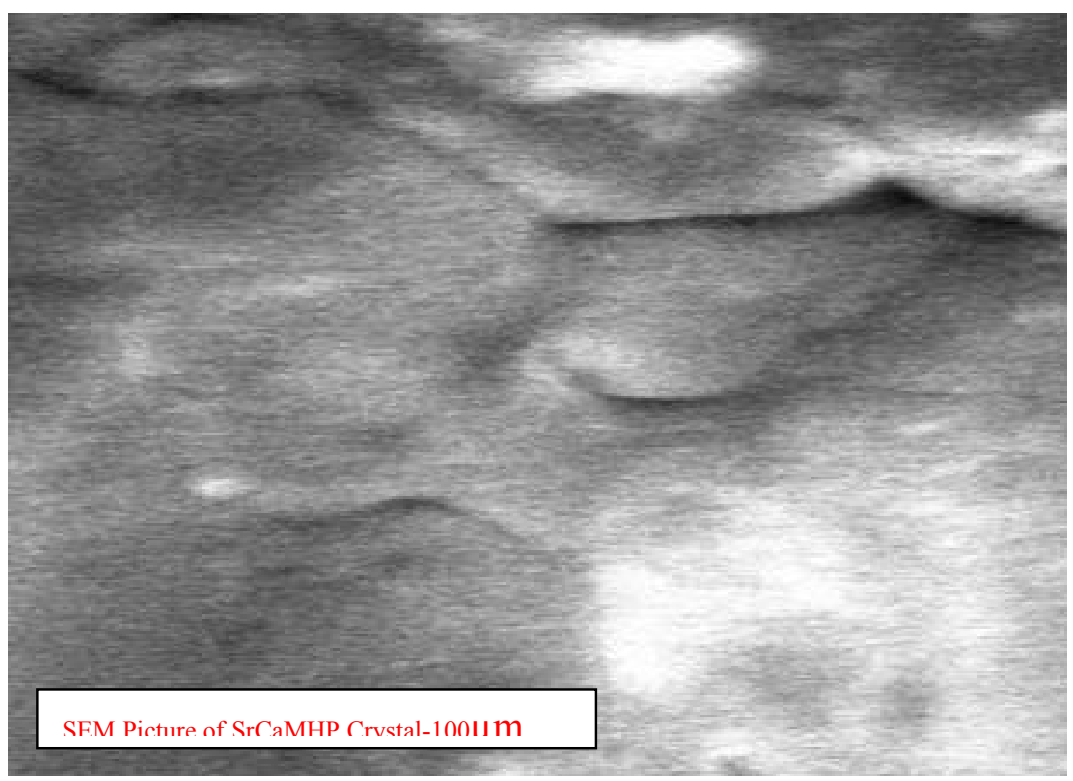

Fig-11.SEM picture of SrCaMHP crystal

\subsection{X-ray Diffraction of SrCaMHP Crystal}

The XRD results revealed the crystalline property of crystal. The XRD pattern and diffraction indices of the SrCaMHP crystals were recorded. Using the programme (Proszki) the lattice parameters of the SrCaMHP crystal were calculated. The lattice parameters are $a=10.03 \AA, b=10.21 \AA, c=10.58 \AA, \alpha=90.20^{\circ}, \beta=90.02^{\circ}, \gamma=90.08^{\circ}$. The volume of the unit cell of the SrCaMHP crystal is $1083.46\left(\mathrm{~A}^{\mathrm{o}}\right)^{3}$. From this data, one can identified and confirmed the SrCaMHP crystal system is triclinic [21-23].

\section{CONCLUSION}

The crystal structure, growth morphology, chemical constituents, surface morphology and TGA/DTA analysis of strontium calcium hydrogen phosphate (SrCaMHP) crystals have been investigated. The SrCaMHP crystals are grown in three different growth faces under various growth conditions. Among them, the laser exposed growth medium is observed to show better nucleation reduction and no crystals were formed, because of the inability to attain super saturation. In sun light exposed medium partial nucleation are observed, since average sunlight exposures to the growth medium are only eight hours per day. FTIR spectrum is recorded and the functional group frequencies of SrCaMHP crystal are analyzed, which confirm the SrCaMHP chemical constituents. Chemical etching studies are carried out at room temperature. The etch pits and the crystal defects are noted. SEM studies identified the surface morphology of grown crystal. The decomposition temperature, percentage of loss of grown crystals is recorded in TGA/DTA analysis. Single crystal XRD data gives the SrCaMHP crystal system with a triclinic structure. 


\section{References}

[1] Sundaramoorthi.P,. National conference on recent trends in material science and technology. Proceeding, (2005) 72.

[2] Sundaramoorthi.P, Tenth National seminar on crystal growth, Proceeding, (2005) 31.

[3] Sudaramoorthi.P Asia Journal of Chemistry, Vol 19-(4) (2007) 2783-2791.

[4] Hnisch, H.K, Garcia-Ruiz J.M, J.Crystal Growth, Vol 75 (1986) 195.

[5] Hnisch, H.K, Garcia-Ruiz.J.M, J.Crystal Growth ,Vol 75 (1985) 203.

[6] Pecsok, R.L., Shields.L.D., Cairns.T., McWillian.I.G., Modern methods of chemical analysis, John Willy\&Sons Inc.,Newyork (1976) 438-442.

[7] Henisch.H.K, Crystals in Gel and Liesegang Rings, (Cambridge University press) Cambridge (1986) 11.

[8] Socrater.G, Infrared Cha. Group Friq.(John willy Edi.) Chichester (1980).

[9] Hatscheck.E, J. Kollid, Z.Vol 37 (1936) 297.

[10] Year, Chin etal ,J. Urology ,Vol 86.(1961) 838-854.

[11] Corns C.M, J.Ann. Clin. Bio-Cherm, Vol 20 (1983) 20-35.

[12] Hesse.A, Bach.D, Stone analysis by infrared, spectroscopy, In., Urinary stones, Clinical and laboratory Aspects, (Edi., Alan Rose, University Park Press) Baltimore, (1982) 87105.

[13] Gilman. J.J.,Johnsion.J, and SearsG.W , J.App..Physics., Vol 29 (1958) 749.

[14] Gilman.J.J, etal, J.App.Physics, Vol 27 (1956) 1018

[15] Fisher.J.C, In: Dissolutions and Mechanical Properties of Crystals (John Wiley and sons Edi), New York (1957).

[16] New Kirk.J.B, In: Director observation of Imperfection in crystals (Inter science Publishers) New York (1962).

[17] Taukamot, K, J. Crystal. Growth, Vol 61, (1983) 199.

[18] Gates.H.C, Thirty years of progress in Surface Science, In: Crystal growth and characterization, North Holland. (1975)

[19] Bethage.H, etal,Electron Microscopy in Solid State Physics (Elsever Edi) Amsterdom (1987).

[20] Albon.N etal, In: Growth and Perfection of Crystals(John Wiley Edi.) New York (1958).

[21] Machennan.G, Reevers.C.A, J.Acta crystals, Vol 8, (1955) 579.

[22] Curry.N.A,Jones.D.W, J.Chem.Soc., A (1971) 3725. 